\title{
Shared objects in conjoined VPs in Germanic ${ }^{1,2}$
}

\author{
Peter Sells \\ University of York
}

\begin{abstract}
I discuss a construction involving conjoined VPs, in which an object in the first conjunct is intuitively shared into the second conjunct, where it is phonologically null. The construction as a phenomenon appears in all of the Germanic languages, with some variation. Building on Sadock (1998) and Vikner (2003) I investigate the shared object structures in several languages from the family, making new or slightly nuanced proposals about the points of cross-linguistic variation.
\end{abstract}

\section{Introduction}

Vikner (2003) has two main themes. Starting with the idea of there being conjoined VP structure in German in which an object in the first conjunct is shared into the second conjunct, he argued that this structure is paralleled in the relevant senses in Yiddish, building on Sadock's (1998) account of the shared object construction in that language. Vikner used this as part of an argument that Yiddish is underlyingly an OV language, like German,

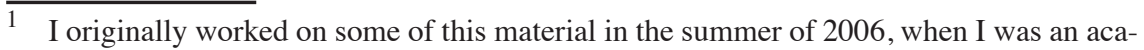
demic visitor at Aarhus University, generously sponsored by Sten. We planned to write a paper on this topic together, but at that time we could not get a good handle on what was going on. Now that we are older and possibly wiser, no longer prisoners of the past, I felt that this might be the right opportunity to revisit the topic. I am very happy to present the result to Sten as recognition of our 20+ years of professional and personal camaraderie.

2 For assistance with the examples and the generalizations, I am very grateful to Laura Kragsnæs Balling, Ken Ramshøj Christensen, Magdalena Kaufmann, Shin-Sook Kim, Johannes Kizach, Helge Lødrup, Jerry Sadock, Sten Vikner and Hanna de Vries. The new data presented here were collected in 2006 and 2019. Special thanks to Terje Lohndal for recent data help.

Ken Ramshøj Christensen, Henrik Jørgensen \& Johanna L. Wood (eds.). 2019.

The Sign of the V-Papers in Honour of Sten Vikner.

Dept. of English, School of Communication \& Culture, Aarhus University, pp. 545-571, doi:10.7146/aul.348.115. (C) The author(s). 
even though its surface strings often show VO order. The second aspect of Vikner's paper is the question of how much variation there is in closely related languages (e.g. languages belonging to the same family, such as Germanic). He argued that while the Scandinavian languages also have what appears abstractly to be the same kind of shared object construction, they have quite a different syntax for it, which he related to them being VO languages.

What I will call the "shared object construction" seems to be present in all the Germanic languages - though entirely absent in English - and is possibly a familial property. I will argue here that while there are differences between German and Mainland Scandinavian, they are smaller than Vikner (2003) suggested, with Yiddish falling in between. As we move geographically further, Icelandic differs to a greater degree, and perhaps has the properties Vikner attributed to all Scandinavian.

The construction in question is illustrated by the German examples in (1b). Examples like this were originally discussed in Sadock (1998).

\section{(1) German}

a. die Frau hat [eine Gans $]_{\mathrm{i}}$ herausgenommen und sie $_{\mathrm{i}}$ auf the woman has $[\text { agoose }]_{\mathrm{i}}$ out.take.PTCP and her $\mathrm{i}_{\mathrm{i}}$ on den Tisch gestellt.

the table put.PTCP

'the woman took out a goose and put it on the table.'

b. die Frau hat the woman has [eine Gans] [a goose] herausgenommen und auf den Tisch gestellt. the table put.PTCP

(1a) is the full expression, with an overt pronoun in the second conjunct agreeing with its antecedent in the first conjunct. Of specific interest is the fact that the object in the second conjunct can also be null, which I will indicate by ' _'; this null object construction is found in some form throughout Germanic. (1b) means the same as (1a), and the object eine Gans is intuitively shared in(to) both VPs.

Briefly, this chapter is organized as follows. Section 2 concerns the properties of the shared object construction in Continental Germanic. In section 3, I move on to Mainland Scandinavian and the main points of difference with Continental Germanic. In section 4, I make a proposal for 
the analysis and look more at the interpretation of the construction. Section 5 brings in Icelandic, which appears to have conflicting properties. Section 6 is a conclusion with pointers to future research.

\section{Continental Germanic}

\subsection{German}

In contrast to examples like (1b) with a periphrastic tense, examples with simple present or past tense do not allow the null object:

(2) die Frau nahm eine Gans heraus und stellte *(sie) auf den Tisch. the woman took a goose out and put *(her)on the table

The generalization noted by Sadock and Vikner is that the German examples involve VP conjunction and are grammatical only if each conjoined VP contains a verb. (2) is ungrammatical as each verb is clearly in its main clause V2 position. On the assumption that the main verb is generated as the head of VP but appears on the surface in C in a V2 clause, whatever is conjoined in (2) does not involve VPs headed by V, in the surface structure. In contrast, (1b) has two surface VPs: one headed by the participle (heraus) genommen and the other by the participle gestellt.

Example (2) is grammatical with the pronoun retained in the second conjunct, and that would involve coordination at some clausal level higher than VP. Repositioning the second verb, to create a surface VP, makes the example completely ungrammatical regardless of the presence of the pronoun:

(3) *die Frau nahm eine Gans heraus und (sie) auf den Tisch stellte. the woman took a goose out and (her) on the table put

It is not necessary that the conjoined verbs be non-finite, only that they be within their VPs. Hence, while the null object version of (2) is ungrammatical, exactly the same set of words is fine, in an embedded clause without V2, and with the verbs in their base position in VP.

(4) a. ...weil die Frau [eine Gans herausnahm] und [sie auf den because the woman [a goose out.took] and [her on the Tisch stellte]. table put] 
b. ...weil die Frau

[eine Gans herausnahm] und [ auf den because the woman [a goose out.took $]$ and [ on the Tisch stellte]. table put]

The acceptability of (4b) supports the idea that the finite verb does not leave the VP in German, except for V2 contexts (i.e. there is no V-to-T for tense, independent of V2).

As we will see for several languages, there is a preference that what is conjoined should be a "small VP", so (5b) is preferred to (5a), though (5a) is somewhat acceptable:

a. er soll_ [eine Gans herausgenommen haben und _ auf den heshould [agoose out.take.PTCP have and_on the Tisch gestellt haben]. table put.PTCP have]

'he should have taken a goose out and put (it) on the table.'

b. er soll [[eine Gans herausgenommen und _ auf den Tisch he should [[a goose out.take.PTCP and_on the table gestellt] haben]. put.PTCP] have]

In (5b), haben heads the infinitival complement to soll, and within that the participial complement to haben is the VP which is internally conjunct. Hence, the smaller VP for the domain of conjunction is preferred. The overt-pronoun versions of the examples in (5) are both fully and equally acceptable.

We can make two other observations about the German data. First, the object that is shared with both VPs may be quantified:

(6) a. er hat alle Dosen herausgenommen und _ mit einem he has all cans out.take.PTCP and — with a Messer geöffnet.

knife open.PTCP

'he has taken out all (the) cans and opened (them) with a knife.' 
b. er hat jede Dose herausgenommen und _ mit einem he has all cans out.take.PTCP and — with a Messer geöffnet. knife open.PTCP 'he has taken out every can and opened (it) with a knife.'

I take these data as evidence that the object is outside the first conjunct and thereby c-commands the empty position in the second conjunct, essentially derived as Across-The-Board movement out of the conjoined VPs.

Second, the following examples support the same structural assumption, as they show that the surface position of the object defines the left edge of the conjoined VP. (7b) is strange as gestern must scope over both conjuncts but heute falls within that scope, in the second conjunct. In contrast, (7a) is fully acceptable, presumably involving ellipsis within a conjoined structure larger than VP. So the oddness of (7b) is due only to the shared object construction. Reversing the order of object and adverbial in the first conjunct gives the corresponding examples in (8) which are both fully acceptable.

(7) a. er hat gestern dieses Buch gelesen und es heute he has yesterday this book read.PTCP and it today weiterempfohlen. recommend.PTCP 'he read this book yesterday and recommended it today.'

b. ??er hat gestern dieses Buch gelesen und _ heute he has yesterday this book read.PTCP and_today weiterempfohlen. recommend.PTCP

(8) a. er hat dieses Buch gestern gelesen und es heute he has this book yesterday read.PTCP and it today weiterempfohlen. recommend.PTCP

'he read this book yesterday and recommended it today.'

b. er hat dieses Buch gestern gelesen und heute he has this book yesterday read.PTCP and_today weiterempfohlen. recommend.PTCP 
Crucially, (7b) shows that dieses Buch marks off the conjoined structure, which entails that gestern is above the conjoined structure, and therefore scopes over both. This leads to the interpretive clash with heute. In (8b), each adverbial is within its own VP. All the data considered so far are consistent with (9), which is effectively what is proposed in Sadock (1998) and taken over in Vikner (2003):

The construction in German involves an object just external to and shared into a conjoined VP structure, within which each VP must be headed by $\mathrm{V}$.

The intuition that I will follow for the rest of the paper is that such an object is effectively a "secondary topic" within the clause - a "secondary" topic on the assumption that the initial phrase in a V2 clause is the primary topic. In German, the secondary topic properties of the shared object are structural as well, for the object c-commands precisely the syntactic material that it has scope over, which is a conjoined VP. The object is represented as OBJ in (10), the structure for German. It is perfectly transparent: within the clause, an object is extracted from and shared into two conjoined VPs. This analysis also entails that there is no derivational relationship between the pronoun-object examples and the null-object examples (i.e. a null-object example is not derived by ellipsis from pronoun-object example). This is correct, as none of the constraints on the null-object examples holds for the corresponding pronoun-object ones.

$$
\left[{ }_{V P} \mathrm{OBJ}_{\mathrm{i}}\left[_{V P}\left[\ldots \mathrm{t}_{\mathrm{i}} \ldots \mathrm{V}\right] \text { Conj }\left[\ldots \mathrm{t}_{\mathrm{i}} \ldots \mathrm{V}\right]\right]\right.
$$

In main clauses, it is only possible to have symmetric VP coordination with non-finite verb forms, such as in the examples involving modals and auxiliaries (e.g. (1b) and (5b)). In simple tenses, the single verb must be external to VP, in C, thereby disrupting the symmetric coordination. In (2) the second conjunct must be larger than VP, and (3) appears to be a violation of the Coordinate Structure Constraint: the head of the first VP has moved out, but the head of the second VP is in-situ. In embedded clauses, the finite $\mathrm{V}$ remains in VP, and hence (4b) contrasts with the null-object versions of $(2) /(3)$, as both conjuncts in (4b) are VPs headed by a V.

A final point to be made about these structures involves case. An accusative object in the first conjunct can be related to a dative pronoun in the second, but the dative pronoun cannot be dropped: 
(11) a. Ich habe einen ${ }_{\mathrm{ACC}}$ frierenden Mann gesehen und ihm $\mathrm{DAT}_{\mathrm{D}}$ I have $a_{\mathrm{ACC}}$ freezing.cold man seen and him DAT eine Mütze geschenkt.

a cap given

'I met a freezing cold man and gave him a cap.'

b. *Ich habe einen ${ }_{\text {ACC }}$ frierenden Mann gesehen und _ DAT eine Mütze geschenkt.

However, if both objects would be accusative, a null second object is perfectly acceptable:

a. Ich habe einen ${ }_{\mathrm{ACC}}$ frierenden Mann gesehen und ihn $\mathrm{ACC}_{\mathrm{A}}$ I have $a_{\mathrm{ACC}}$ freezing.cold man seen and him $\mathrm{ACC}_{\mathrm{AC}}$ auf eine Suppe eingeladen.

to a soup invited

'I met a freezing cold man and offered him some soup.'

b. Ich habe einen ${ }_{\mathrm{ACC}}$ frierenden Mann gesehen und _ ${ }_{\mathrm{ACC}}$ eine Suppe eingeladen.

In the mixed-case examples, no matter in what order the dative- and accusative-governing verbs come, the example with a null object is unacceptable:

a. Ich habe einem
ihn $_{\mathrm{ACC}}$ auf eine Suppe eingeladen.

b. *Ich habe einem ${ }_{\mathrm{DAT}}$ Mann eine Mütze geschenkt und __ACC auf eine Suppe eingeladen.

In other words, case-matching is only required in the shared object construction. The simplest way to account for this is through an analysis in which the overt object directly "belongs" in both object positions, exactly as structured in (10).

The idea that I develop is that most other Germanic languages differ from German only in surface syntactic properties: the shared object does not, or at least need not, c-command over the conjoined VPs, but it still has the information-structure status of a secondary topic. I will show that the 
conjoined VP structure (VP and nothing larger) holds in Yiddish and in the mainland Scandinavian languages, until we get as far as Icelandic, which is perhaps one further step removed from German.

\subsection{Dutch}

For the sake of completeness, I note that Dutch behaves exactly like German in the respects above, with the same contrast in simple tenses between main/V2 clauses and embedded/non-V2 clauses:

(14) De vrouw heeft een gans gebraden en(hem) op tafel gezet. the woman has a goose roast.PTCP and (him) on table put.PTCP

(15) De vrouw braadde een gans en zette *(hem) op tafel. the woman roasted a goose and put *(him) on table

(16) Ik zag dat [de vrouw een gans braadde en (hem) op tafel zette]. I saw that [the woman a goose roasted and (him) on table put]

\subsection{Yiddish}

While German is fairly strictly head-final in its clausal syntax, with the exception of V2 in main clauses, Yiddish shows more freedom of constituent order. Nevertheless, Vikner (2001) argues that major generalizations about Yiddish clausal syntax align it much more closely with Continental Germanic (OV) rather than Scandinavian (VO), once independent conditions on the placement of the finite verb are factored out. The original shared object construction examples are from Sadock (1998). (17b) is slightly modified here from his original (thanks to Sadock p.c.), for ease of presentation:

(17) a. Di yidene hot aroysgenumen eyn gandz un the woman has out.take.PTCP one goose and avekgeleygt af'n tish. down.put.PTCP on the table 'The woman has taken out one goose and put (it) down on the table.'

b. Di yidene hot genumen eyn gandz un _ gevorfn the woman has take.PTCP one goose and throw.PTCP oyf der tsveyter. onto the second

'The woman has taken one goose and thrown (it) onto the second.' 
As in German (3), main clause examples with only finite verbs are unacceptable:

(18) ??Di yidene nemt aroys eyn gandz un leygt _ avek af'n tish. the woman takes out one goose and puts_down on the table 'The woman takes out one goose and puts (it) down on the table.'

Sadock notes (1998: 224): "I have never found a textual example of a missing pronoun with a finite verb." Now this generalization extends to embedded clauses, in contrast to German: examples with complex tenses and conjoined participial VPs are fine, but examples with conjoined verbs in simple tense are bad:

$\ldots$ vayl er hot genumen aroys a ganz un _ gestellt
because he has take.PTCP out one goose and_put.PTCP af'n tish.

on the table

*... vayl er nemt aroys a ganz un_stellt af'n tish.
because he takes out one goose and_puts on the table

(20) contrasts with German (4b) and Dutch (16). The reason for the difference is that the finite verb raises to (clause-medial) $\mathrm{T}$ in all finite clauses in Yiddish (Vikner 1995, 2001), so the strings nemt aroys a ganz and stellt af'n tish in (20) are not surface VPs. Due to this raising to T, Yiddish contrasts with German in that a finite verb may never be final, even in an embedded clause:

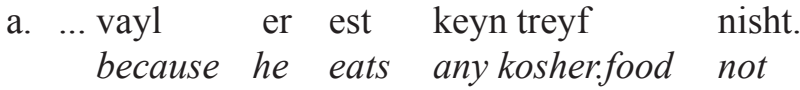
b. *... vayl er keyn treyf nisht est. because he any kosherfood not eats

This follows from the fact that Yiddish has V-to-T in all finite clauses, and $\mathrm{T}$ precedes VP. (V2 clauses perhaps further involve V-to-C.) The fact that Yiddish (20b) is bad while (4b) is good in German shows that the construction involves VP-coordination, which is disrupted if the finite verb 
leaves VP and surfaces in T or in C. If the null object in any of (17-20) is replaced by the correct overt pronoun, the example involves clause-level conjunction of some kind, and is acceptable.

Compared to German, constituent order within VP is more flexible in Yiddish, leading to the famous debate about whether Yiddish is fundamentally OV or VO. One of the points of Vikner (2003) is to argue that Yiddish patterns with German in ways that support the OV analysis of Yiddish. To account for examples like (22) (Sadock's original example), he assumes that the shared object eyn gandz is lowered/extraposed into the first conjunct VP, from a VP-external position such as in (10).

Di yidene hot [aroysgenumen eyn gandz] un
the woman has [out.take.PTCP one goose] and
[_avekgeleygt af'n tish].
[_ down.put.PTCP on the table $]$

'The woman has taken out one goose and put (it) down on the table.'

As we will see shortly, the surface form of the VPs in (22), in which the shared object is within the first VP, is a surface form which also appears throughout Mainland Scandinavian. The minimal difference between German and Yiddish is that the status of the shared object as a secondary topic is overt in German (as in (10); and Dutch), but is an abstract relation in Yiddish and the other languages.

$\left[{ }_{V P}\left[{ }_{V P} \ldots O \mathrm{OBJ}_{i} \ldots\right]\right.$ Conj $\left.\left[{ }_{V P} \ldots t_{i} \ldots\right]\right]$ where each VP has an overt head

Yiddish shares with German and Dutch the fact that each VP must be headed by $\mathrm{V}$, but does not share the transparent overt positioning of OBJ.

\section{Mainland Scandinavian}

\subsection{General overview - Mainland Scandinavian contrasted with}

\section{German}

The shared object construction is well-documented in Mainland Scandinavian (MSc), going back at least to Falk \& Torp (1900) for Danish (cited in Vikner 2003: 372). Faarlund et al. (1997: 715) comment on it for Norwegian, and it is mentioned for Swedish in Egerland (1996: 290) and in Teleman et al. (1999: 914, 948, 962). The construction in Norwegian is 
discussed from a more theoretical perspective in Åfarli and Creider (1987), Johnsen (1988), and in detail in Larson (2005). Unlike in Continental Germanic, there are quite strong pragmatic constraints on the construction in MSc. From the literature just cited, it seems that these restrictions vary slightly by language, variety, and even perhaps speaker. I do not attempt to discriminate between varieties, and in this section, examples are drawn from Danish and Norwegian.

Vikner reports for Danish that the first VP should provide an immediate pre-condition for the second: it describes a situation "where the two actions are very closely connected such that the first forms the basis for or the introduction to the second" (Falk \& Torp 1900: 268, in Vikner 2003), as in (24).

(24) Danish (Falk \& Torp 1900: 268, in Vikner 2003)

Så skrev jeg et surt klagebrev og sendte (det) til dem. then wrote I a angry complaint.letter and sent (it) to them 'Then I wrote an angry letter of complaint and sent (it) to them.'

The reader will have noticed that (24) is acceptable as a shared object example with simple-tense verbs, yet it is a main clause example. This is one data point on which Scandinavian differs from Continental Germanic. Like (24), the Danish example in (25) is grammatical, unlike its direct counterparts in the languages previously discussed (see (2), (15), (18)).

(25) Danish (Vikner 2003: 372)

Kvinden tog en gås frem og lagde (den) på bordet. the.woman took a goose out and put (it) on the.table 'The woman took a goose out and put (it) on the table.'

My proposal will be that examples like (25) actually do still involve VPcoordination, and that the second conjunct is a VP headed by a (finite) verb. It is worth noting explicitly that whatever is going on in the first conjunct is not Object Shift - which is present in Scandinavian but not in Continental Germanic - as Object Shift does not apply to full NPs in MSc, and Object Shift only applies in main clauses with simple tenses. The shared object construction involves full NPs (as in (25)), and compound tenses (28a) below).

In addition to the object which appears in the first conjunct, the other 'marker' of the construction is the specific conjunction, og in Danish 
or Norwegian. Even adding in både ('both') renders the shared object construction ungrammatical (Åfarli and Creider 1987: 343). Larson (2005: 21) notes that "nothing can intervene between the conjunction and the verb of the second conjunct". It is possible to have adjuncts in the second VP, as long as they follow the head verb:

(26) Norwegian (Larson 2005: 20)

Han tar en mynt og legger_ raskt/forsiktig på plass. he takes a coin and lays_quickly/carefully in place

What is interesting about the MSc examples is that the structures are partially asymmetric, to a degree that I cannot claim to fully understand, while also being symmetric enough to allow the shared object interpretation. This is perhaps related to their underlying VO property, and differs from German.

The asymmetry in the structure is this: in a V2 clause it is the verb from the first conjunct which raises out of VP to $\mathrm{T}$, and then $\mathrm{C}$, while the second conjunct - which is a VP immediately preceded by $o g$ - behaves somewhat like an adjunct. The Norwegian examples below from Johnsen (1988; examples (15)) illustrate this (see also Larson 2005: 45). The examples are notated as follows. The initial bracketed phrase is a non-subject whose base position is marked by [ _ ] The examples also involve the shared object construction, and the overt object in the first conjunct is underlined. In the second conjunct, an overt pronoun or _ marks the (intended) element coreferential with that object.

(27) Norwegian (Johnsen 1988; examples (15))

a. [Hylla] tok han en bok fra [_] og la *den/OK_ på bordet. [the.shelf] took he a bookfrom [__ and put ${ }^{*}$ it/OK_on the.table

b. [Bordet] tok han en bok og la *den/?? _ på [_]. [the.table] took he a book and put *it/?? _ on [_ ]

(27a) is fully acceptable with the shared object construction. However, the initial phrase hylla is only extracted from the first conjunct, as indicated, and has no syntactic role in the second conjunct. If the conjoined structure in (27a) were fully symmetric, we would expect the Coordinate Structure Constraint to rule the example out; so we must conclude that the second conjunct og la på bordet is more like an adjunct. Johnsen points out that the overt-pronoun version of (27a) is probably not ungrammatical, but rather 
that there is an overwhelming preference to take the fronted topic hylla as the antecedent of the overt pronoun den, leading to a strange interpretation.

In (27b), the topicalization of bordet comes from the second conjunct. Once again the overt pronoun is out, but importantly, the shared object version is also not very good, which suggests that the second conjunct has an adjunct-like status - as a shared object construction the example should be fine, and has the (degraded) status of extraction out of an adjunct.

\subsection{Mainland Scandinavian - VP-level conjunction}

Danish examples corresponding to the basic German examples are given in (28). As we have seen, in Scandinavian, there is no requirement that each conjunct, which is a notional VP, should be headed by a V itself. Hence, (28b) is grammatical, even with a null object in the second conjunct.

$$
\text { Danish (Vikner 2003: 371) }
$$

a. Kvinden har taget en gås frem og lagt (den) the woman has take.PTCP a goose out and put.PTCP (it) på bordet. on the.table

b. Kvinden tog en gås frem og lagde (den) på bordet. the woman took a goose out and put (it) on the table 'The woman took a goose out and put (it) on the table.'

As (28b) is a V2 clause, the first verb tog cannot be in its base position in $\mathrm{VP}$, but must be in $\mathrm{T}$ or $\mathrm{C}$, depending on the particular analysis of subjectinitial V2 clauses. It is exactly this positioning of the finite verb which renders the corresponding examples out in Continental Germanic. Vikner (2003) assumed that the second conjunct of such examples also shows main clause structure - a CP in his analysis - and from that concluded that the shared object construction in Scandinavian involves coordination at the CP level, to allow for examples like (28b). I want to re-evaluate this conclusion. The string lagde (den) på bordet can of course be a surface VP in Danish (e.g. in embedded clauses).

There seems to be straightforward evidence that the shared object construction cannot have a domain larger than VP in the MSc. For although both examples in (28) are acceptable, (29) is not (also noted for Norwegian by Larson 2005), if the second object is null: 


\section{(29) Danish}

Kvinden har taget en gås frem og har lagt the.woman has take.PTCP a goose out and has put.PTCP *(den) på bordet.

*(it) on the.table

If the shared object construction is assumed to operate on a domain larger than VP, it is not obvious how to rule (28) in and (29) out. By that assumption, the conjunction would operate at clausal level, somewhere around CP, and whatever licenses (28b) should license (29). (29) appears to be strong evidence that the shared object construction in Danish does not involve clausal coordination (TP or CP), and this is confirmed by (30). This example shows that if there are multiple verbs, only the main verb can appear in the second conjunct with the missing object:

\section{(30) Danish}

Kvinden må have taget en gås frem og the.woman must have take.PTCP a goose out and (*have) lagt__ på bordet. (*have) put.PTCP _ on the.table

Again, the right conjunct sequence have lagt pa bordet is a perfectly fine non-finite VP, but it cannot appear in the shared object construction. In fact, what is coordinated must be quite a "small" VP - basically, the smallest kind of VP possible.

Another important observation is that negation can only occur in the first conjunct (Larson 2005: 19). (31) has negation in the second conjunct, and is only grammatical with the overt pronoun. (31) contrasts with (32), with negation in the first conjunct, and which Larson reports prefers the null-object version of the second conjunct in preference to the overt-object version:

(31) Norwegian (Larson 2005:18-19)

Jens rettet et brev og sendte *(det) ikke til England. Jens corrected a letter and sent *(it) not to England 'Jens corrected a letter and did not send it to England.' 
Jens rettet ikke noe brev og sendte (det) til England. Jens corrected not anyletter and sent (it) to England 'Jens didn't correct any letter and send it to England.'

What is wrong in (31) as a shared object example is that there is no way to linearize the right conjunct string sendte ikke til England, on the assumption that the constituent can be no larger than VP. To derive the order in which the verb precedes negation, the verb must raise out of VP at least to T, but then the conjunct must be larger than VP. If the verb sendte remains in VP, ikke would have to be VP-internal, which is not possible. As the overt-pronoun version of (31) is acceptable, there is no obvious pragmatic account of why the null-object version should be bad. Hence this seems to be further evidence that the second conjunct in the shared object construction is a VP.

\section{The analysis - Secondary Topic}

\subsection{Secondary topic}

My proposal is that the shared object is a secondary topic in the clause, and due to this status may be shared into the second VP conjunct. Essentially, what is directly structurally represented in German is covertly encoded only through information structure in the other languages. The notion of secondary topic as it has been articulated in Nikolaeva (2001: 26) and Dalrymple and Nikolaeva (2011: 55), given in (33), does seem quite appropriate here:

(33) A secondary topic is "an entity such that the utterance is construed to be ABOUT the relationship between it and the primary topic" (Nikolaeva 2001: 26).

It is notable that most of the examples of the shared object construction are subject-initial (and V2) clauses. As such, the subject would be the primary topic, and then the relation to secondary topic given in (33) looks very similar to what Falk \& Torp (1900) observed (see the text above (24)).

It would be remarkable if the shared object construction were restricted to subject-initial clauses, and there is no such strong restriction (see (24) and (27a) above). However, it seems that the subject-initial examples are most natural. Examples which have a non-subject in initial position typically involve a locational or temporal first phrase. Norwegian speakers 
find examples like (34) and (35) relatively acceptable, but perhaps not quite fully acceptable:

(34) Norwegian

Hver jul har Jens skrevet brev og every Christmas has Jens write.PTCP letters and sendt__ til vennene sine. send.PTCP _ to friends REFL

'Every Christmas Jens has written letters and sent (them) to his friends.'

(35) Selv om høsten har vært svært travel, har Jens although autumn has be.PTCP verybusy, has Jens skrevet julebrev og sendt _ til England. write.PTCP Christmas.letters and send.PTCP — to England 'Although Autumn has been very busy, Jens has written Christmas letters and sent (them) to England.'

In these examples, 'Jens' is not formally the syntactic topic, but it is clear that the examples are 'about Jens' (and what he has done). In her observation about the shared object construction Larson (2005: 24) notes for Norwegian that the first VP must "express an action in which an agent takes possession of or control over an object".

One interesting property of MSc is that the shared object construction is quite degraded if the first object is itself a pronoun, as seen in these Danish examples:

\section{(36) Danish}

a. Han tog den ned fra hylden og lagde ??(den) he took it down from the.shelf and put ??(it) på bordet. on the.table

b. Han har taget den ned fra hylden og he has take.PTCP it down from the.shelf and lagt ??(den) på bordet. put.PTCP ??(it) on the.table 
However, such examples can be improved with a fuller context:

(37) A: Where is the cloth? I can't find it anywhere!

B: Måske har han taget den ned fra hylden perhaps has he take.PTCP it down from the.shelf og lagt ?(den) på bordet. and put.PTCP ?(it) on the.table

If the secondary topic must be interpreted in some way relative to the primary topic/agent, it may be that there is not enough information in the examples in (36) for a successful interpretation in the absence of a more descriptive NP.

One consideration that is obviously relevant here is the Empty Left Edge Condition of Sigurðsson \& Maling (2010), a general condition which makes clause-internal gapping or ellipsis contingent on that clause having an "empty" left edge. Simple recipe-style object-drop examples illustrate the general phenomenon; an object cannot be missing unless the subject is:

(38) Take three eggs. *(You) beat in a bowl.

The condition that they argue for extensively is (39), as a descriptive generalization:

(39) Empty Left Edge Condition (Sigurðsson \& Maling 2010: 62)

The left edge of a clause containing a silent referential argument must be phonetically empty (in a language or construction X).

They discuss the shared object construction as part of a range of different contextually-reduced clauses, including (40) from Norwegian:

(40) Norwegian (Sigurðsson \& Maling 2010: 73)

Han hogg juletre og selde _ i byen. he cut.down Christmas.tree and sold _ in town 'He cut down a Christmas tree and sold it in town.'

Clearly all shared-object examples which involve VP-coordination necessarily respect the ELEC. Its significance to the topic of this paper becomes particularly relevant when we come to consider Icelandic, in section 5 below. 


\subsection{Interpreting the null object}

Larson (2005: 37) proposes that the null object is interpreted as an E-type pronoun (Evans 1980). The object position in the second conjunct is not c-commanded by the overt object in the first conjunct, so this suggests that there is some anaphoric relation between the two surface positions. Larson argues that the interpretation of a shared object example shows the "maximality effect" which is the hallmark of an E-type interpretation.

(41) Norwegian (Larson 2005: 37)

Jens skrev tjue brev og sendte _ til England. Jens wrote twenty letter and sent _ to England

'Jens wrote twenty letters and sent (them) to England.'

Larson's observation is that (41) is infelicitous if Jens wrote twenty letters but only sent ten to England: the example must mean that Jens wrote twenty letters and what he sent to England were the twenty letters he had written. In other words, the object does not have wide scope over the whole example, as one might expect, say, from QR. This interpretation is seen more clearly if the object is explicitly quantified:

(42) Jens skrev bare to brev og sendte (dem) til England. Jens wrote only two letter and sent (them) to England 'Jens wrote only two letters and sent them to England.'

Larson's observation is that with or without the overt pronoun in the second conjunct, what the example means is that Jens wrote only two letters and what he sent to England are just those two letters he had written. The example does not mean 'there are only two letters which Jens both wrote and sent to England', allowing that he wrote other letters that he did not send. Even without invoking the E-type interpretation, the secondary topic idea put forward here should also capture the relevant property as it necessarily entails that the object's interpretation is subordinate to the subject's. (41) effectively means 'Jens wrote twenty letters and what he did with them is send them to England'.

Larson's E-type proposal and the secondary topic proposal both founder on examples where the shared object is a negative quantifier, taken up in the following subsection. On the basis of either proposal, we would expect negative quantifier examples to be bad, but in fact they are good. Evans (1980) showed that a negative quantifier cannot antecede a pronoun 
with an E-type interpretation; and it seems implausible that something like ingen brev ('no letter') could be a topic, albeit a secondary one, if the term "topic" is to mean anything.

Larson's specific proposal for examples like (41) and (42), given here in (43a), is that the second conjunct contains an empty operator Op which raises to the edge of that conjunct, binding in a trace in argument position. The Op is the E-type pronoun: it takes its interpretation from the preceding conjunct. In addition, for the negative quantifier examples, Larson proposes a secondary 'last resort' structure in which the first conjunct's object raises and scopes over both conjuncts, and therefore directly binds Op:

(43) a. preferred structure, E-type interpretation for Op:

$\left[\ldots\right.$ OBJ ... Conj $\left[\mathrm{Op}_{\mathrm{i}} \ldots \mathrm{t}_{\mathrm{i}} \ldots\right]$

b. last resort structure, OBJ binds Op:

$$
\left[\ldots \mathrm{OBJ}_{\mathrm{i}}\left[\ldots \mathrm{t}_{\mathrm{i}} \ldots\right] \text { Conj }\left[\mathrm{Op}_{\mathrm{i}} \ldots \mathrm{t}_{\mathrm{i}} \ldots\right]\right]
$$

To be more consistent with the secondary topic idea, I will propose a slightly different structure for (43a). With regard to (43b), this last-resort structure does not need to be invoked, as negative quantifiers in Scandinavian already have the necessary positional properties (see section 4.3 below).

I provide only an outline analysis here. The secondary topic is only overtly positioned outside the coordination in German and Dutch (see (10)), which means for all the other languages that we need a covert representation. I suggest reimagining Larson's analysis, with the empty operator now representing the secondary topic, shown in (44) as $\mathrm{Op}_{\mathrm{ST}}$. If this were the emptiest of operators, we could assume that it binds the OBJ in the first conjunct, taking all its features and its reference from OBJ, and at the same time binds an empty object position in the second conjunct, represented here as a trace. With an index, the operator is represented as $\mathrm{Op}_{\mathrm{ST}-\mathrm{i}}$. It is important for the case-matching facts in German ((11-13) above) and Icelandic ((51-54) below) that the null position in the second conjunct is a trace, so that the case properties are present in or inherited to both object positions.

(44) Secondary Topic structure:

$\mathrm{Op}_{\mathrm{ST}-\mathrm{i}}\left[{ }_{\mathrm{VP}}\left[{ }_{\mathrm{VP}} \ldots \mathrm{OBJ}_{\mathrm{i}} \ldots\right]\right.$ Conj $\left.\left[{ }_{\mathrm{VP}} \mathrm{V} \ldots \mathrm{t}_{\mathrm{i}} \ldots\right]\right]$ 
Effectively, $\mathrm{Op}_{\mathrm{ST}}$ is a scope-marker for the OBJ. (44) is somewhat is similar to the structure proposed (for Icelandic) in Ximenes (2007: 11), for similar reasons. Relevant here is the fact that the OBJ can be in first position in a V2 clause (Larson 2005: 45):

(45) Norwegian (Larson 2005: 45)

Tre brev skrev Jens og sendte _ til England. three letter wrote Jens and sent _to England 'Jens wrote three letters and sent them to England.'

The first-position OBJ still licenses the shared object construction. We know that a VP-internal constituent from the first conjunct can be topicalized directly to first position (see (27a) above). Starting with (44), the OBJ moves to first position, and from this high position, $\mathrm{OBJ}$ binds $\mathrm{Op}_{\mathrm{ST}}$, which in turn binds the two traces as in (46):

$$
\left[\mathrm{CP}_{\mathrm{CP}} \mathrm{OBO}_{\mathrm{i}} \ldots \mathrm{Op}_{\mathrm{ST}-\mathrm{i}}\left[{ }_{\mathrm{VP}}\left[\mathrm{VP}_{\mathrm{VP}} \ldots \mathrm{t}_{\mathrm{i}} \ldots\right] \text { Conj }\left[\mathrm{VP}_{\mathrm{VP}} \mathrm{V} \ldots \mathrm{t}_{\mathrm{i}} \ldots\right]\right]\right]
$$

In Larson's structure (43a), the correct semantics are intended to follow because the $\mathrm{Op}$ in the second conjunct is interpreted as an E-type pronoun taking its reference from the description in the first conjunct. While the gist of the proposal is clear, formally it is not so straightforward how the E-type interpretation is calculated, as the right conjunct is actually a subclausal constituent (TrP) embedded within the first clause (Larson 2005: 175). The alternative structure which I propose, (44), can also give the right semantics for e.g. (42). The point is that the example should entail that Jens wrote only two letters, not that Jens wrote and sent to England only two letters.

As noted above, the secondary topic idea entails that the object is interpreted under the scope of the subject and some action that the subject is taking. In addition, as I noted at the end of section 3.1, the coordinate structure is actually partially asymmetric, with the second conjunct having some adjunct-like properties. Hence the semantics of (42) are possibly quite close to something like Jens wrote only two letters (to send (them) to England), which entails that Jens wrote only two letters. 


\subsection{Negative quantifiers-scope over both VPs}

It is also possible to have the shared object construction when the object is a negative quantifier:

Norwegian (Johnsen 1988; example (14a))

a. Han tok ingen mynter og kastet $(*$ dem) på sjøen. he took no coins and threw (*them) into the.sea

Norwegian (Larson 2005: 41)

b. Han skrev ingen brev og sendte (*den) til England. he wrote no letter and sent (*it) to England 'He wrote no letter and sent it to England.'

These examples would appear to be inconsistent with the 'secondary topic' analysis, as one might expect that something topical would have some positive reference. However, there is an alternative analysis which generates the examples directly. It is clearly established that (object) negative quantifiers in Scandinavian may appear in a surface position that is external to VP, somewhere in TP around where the clausal negation (e.g. ikke) would appear (subject to some restrictions; see e.g. Christensen 1986, Svenonius 2000, Sells 2001). Effectively, this allows the German analysis for precisely this class of elements: from a mid-clause position the negative quantifier c-commands both VPs, and appears to be extracted across-the-board out of both. It is notable that the variant of the examples in (47) with the overt pronoun is completely bad, showing that there is no discourse-antecedent for a pronoun, nor the option of binding by the negative quantifier.

Larson notes that examples with a quantified object in the first conjunct tend to resist a pronoun in the second conjunct but a pronoun is not as bad as in the negative quantifier examples:

(48) Norwegian (Johnsen 1988; example (14b))

a. Han tog hver boks og åpnet (??den) med kniven. he took everycan and opened (??it) with the.knife 'He took every can and opened (it) with the knife.'

b. Han tog hver boks og han åpnet (??den/*_ med kniven. he took every can and he opened (??it/*_) with the.knife 
The null-object version of (48a) is perfectly acceptable, and the overtpronoun version is low in acceptability. (48b) is a similar example which I have created, except with an overt subject in the second conjunct. This rules out the shared-object construction, and with a null object also violates the ELEC (see (39) above). Hence the null-object version of (48b) is completely ungrammatical. However, the overt-pronoun version of (48b) is no better than its equivalent in (48a), which suggests that - for whatever reason - the quantifier hver boks cannot take scope over the conjunction and bind a pronoun in the second conjunct. But if hver boks cannot take scope, something must be licensing the null-object version of (48a) - namely, the shared object construction involving coordination at the VP level.

\section{Icelandic}

Icelandic appears to have the shared object construction (see Larson 2005: 26, Rögnvaldsson 1990, Pouplier 2003, Ximenes 2007). It does not involve the pragmatic restrictions found in MSc, and there is no oddness with a pronoun in the first conjunct (e.g. (51) below). However, there is conflicting evidence as to the correct analysis.

On the one hand, like Yiddish, Icelandic shows V-to-T raising in all finite clauses, even embedded clauses, in which the finite verb should precede medial adverbial elements (e.g. ekki and aldrei respectively in (49); examples from Holmberg 1986), showing that it has raised to T:

a. Рað var gott $\left[_{\mathrm{CP}}\right.$ að $\left[_{\mathrm{TP}}\right.$ hann keypti ekki bókina $]$. it was good $\left[_{\mathrm{CP}}\right.$ that $\left[_{\mathrm{TP}}\right.$ he bought not the.book $]$ 'It was good that he did not buy the book.'

b. Ég veit ekki $\left[_{\mathrm{CP}}\right.$ hvers vegan $\left[_{\mathrm{TP}}\right.$ Sigga setur aldrei hlutina I know not $\left[_{\mathrm{CP}}\right.$ why $\quad \mathrm{C}_{\mathrm{TP}}$ Sigga puts never the.things á réttan stað]. in the right place]

'I do not know why Sigga never puts the things in the right place.'

The shared object construction is possible in simple-tense finite clauses (Thráinsson 2007: 479): $\begin{array}{llllll}\text { Ég tók bókina } & \text { og } & \text { færði } & \text { (hana) eiganda sínumi. } \\ \text { I took the.book } & \text { and } & \text { brought (it) owner } & \text { REFL }\end{array}$ 'I took the book and brought it to its owner.' 
(50) should not be possible as a shared-object example involving VPcoordination, given that foerð $i$ must be in T. It should have the same status as Yiddish (18). As (50) is grammatical, it would appear that the shared object construction in Icelandic involves clausal coordination, at the TP or $\mathrm{CP}$ level. However, there are other data which are inconsistent with clausal coordination, and which argue again for VP-coordination. I present these data in the rest of this section, leaving Icelandic as a puzzle.

Like German, Icelandic requires case-matching in the shared-object construction. Pouplier (2003) reports both versions of (51) as fully grammatical. Each verb selects for a dative object.

(51) Ég hótaði honum ${ }_{\text {DAT }}$ og skipaði (honum ${ }_{\text {DAT }}$ ) að PRO fara. I threatened him DAT $_{\text {and ordered }}\left(\right.$ him $\left._{\mathrm{DAT}}\right)$ to PRO leave 'I threatened him and ordered him to leave.'

Ximenes (2007: 3) provides more evidence in favor of case-matching. In each example below, the object-case requirements of the two verbs differ, and while the overt-pronoun version is grammatical, the null-object version is not.

Ég $_{\mathrm{NOM}}$ keypti sjónvarp ${ }_{\mathrm{ACC}}$ $I_{\mathrm{NOM}}$ bought the.TV $V_{\mathrm{ACC}}$ og skilaði $*\left(\right.$ pvi $\left._{\text {DAT }}\right)$ til eiganda sins. and returned $*\left(i_{\mathrm{DAT}}\right)$

to owner REFL

'I bought the TV and returned it to its owner.'

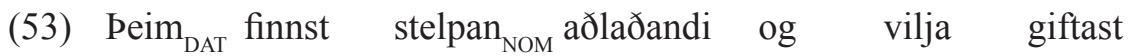
they ${ }_{\mathrm{DAT}}$ find.3SG the.girl ${ }_{\mathrm{NOM}}$ attractive and want.3PL marry *(henni $\left.{ }_{\text {DAT }}\right)$.

$*\left(h_{\text {DAT }}\right)$

'They find the girl attractive and want to marry her.'

$\begin{array}{llll}\text { Peir }_{\mathrm{NOM}} & \text { sjá } & \text { stúlkuna } & \text { og finnst } \\ \text { they }_{\mathrm{NOM}} & \text { see.3PL the.girl } & \text { og } & \text { and find.3SG } \\ *\left(\text { hún }_{\mathrm{NOM}}\right) & \text { álitleg. } & & \\ *\left(\text { her }_{\mathrm{NOM}}\right) & \text { attractive }\end{array}$

'They see the girl and find her attractive.' 
(52) is the simplest example - one verb requires an accusative object and the other a dative object, and so the null-object version of the example is bad. The grammatical versions of examples like (53) and (54) were used by Rögnvaldsson (1990) to argue that what might look like VP-coordination in Icelandic, or even $\mathrm{T}^{\prime}$-coordination, must actually be TP-coordination with a pro subject before the verb in the second conjunct. The argument is this, and seems strong: the verb finna takes a dative subject and a nominative object, and in its finite form finnst shows $3 \mathrm{sg}$ agreement. The verb in the other conjunct takes a nominative subject, and as the subject is chosen to be grammatically plural, the verb shows $3 \mathrm{pl}$ agreement. It cannot be the case, then, that the subject 'they' in (53) and (54) is the subject of both verbs, as those verbs put conflicting case constraints on the subject, and the subject controls different agreement sets on the verbs. The examples must involve clausal coordination with a pro subject in the second conjunct.

While Rögnvaldsson (1990) showed that Icelandic must have clausal (TP) coordination in some examples, such coordinations do not intersect with the shared object construction. The null-object versions of (53) and (54) are bad. In fact, as observed by Ximenes (2007), such examples must be bad. In order to create the structures which require the TP-coordination analysis, we need two verbs which impose different case constraints on their subjects, but then of necessity they will also impose different case constraints on their objects, and so must violate the case-matching constraint on the shared object construction.

Further, if the coordination is above VP, it is not obvious why (55b) is bad (Ximenes 2007: 6):

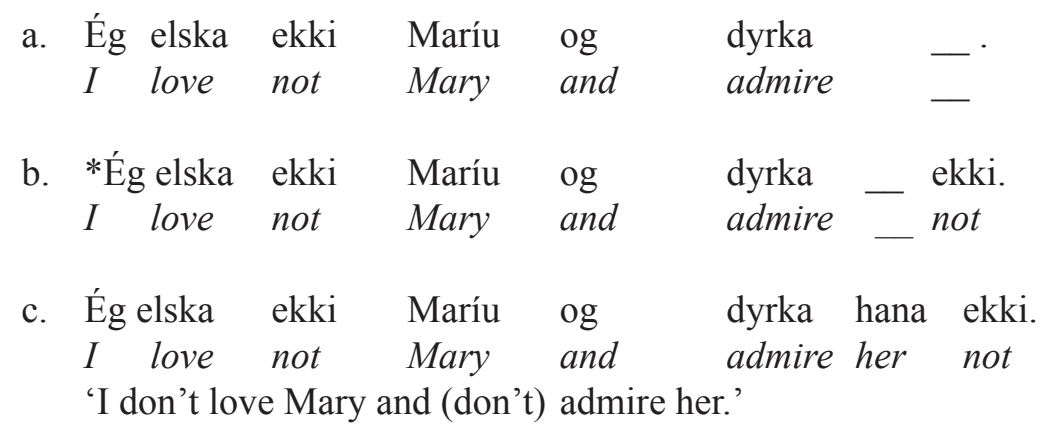

(55c) is grammatical and could be generated as $\mathrm{T}^{\prime}$ - or TP-coordination. Specifically, in the second conjunct, the finite verb dyrka would be in $\mathrm{T}$, followed by the object hana in the object-shift position (somewhere 
within TP, but external to VP), followed by the negation ekki in its base position, also external to VP. This is all perfectly straightforward in Icelandic syntax. The problem is then that there is no way to account for why (55b) is bad: the example satisfies the ELEC ((39) above), and the structure and interpretation would be the same as (55c) except that the second object is null. Ximenes (2007) concludes that Icelandic must also require VP-coordination for the shared object construction. (55b) shows that a combination of $\mathrm{T}^{\prime}$ - or TP-coordination and the ELEC is not enough to account for Icelandic (see also Danish (29)).

In summary, the examples in (49) have been taken to show that a finite verb never surfaces within VP in Icelandic, which would mean that (50) should involve coordination above VP. However, the examples in (55) seem to show that the shared object construction involves VP-coordination.

\section{Conclusion}

I have argued here that fundamentally the shared object construction involves VP-coordination, and that the shared object fits the profile of a secondary topic (see (33)). In German and Dutch, the shared object is external to the conjoined VPs, as schematized in (10). In both these languages and Yiddish, each conjunct VP must be headed in the surface syntax. However, in Yiddish, the shared object is located within the first conjunct VP.

Mainland Scandinavian also involves VP-coordination. As in Yiddish, the shared object is within the first VP. However, there is no requirement that that VP be headed in surface syntax - only the second VP has that requirement. The structure for Mainland Scandinavian is given in (44). Finally, Icelandic seems to show conflicting properties - facts of finite verb positioning suggest that the coordination should be at some clausal level (CP or TP), but facts of case-matching and clausal negation suggest that the coordination is at the VP level, as in the other languages.

There are at least three puzzles that I have left for future research. The first concerns the asymmetry in the structure in MSc (section 3.1). Why does the requirement that each VP be headed hold for Continental Germanic but not for MSc? How does that relate to the fact that the second VP seems to be more adjunct-like in MSc?

The second puzzle concerns the relation between the conjunction word 'and' and one of the verbs. In German and Dutch, the conjunction is immediately adjacent to a preceding verb, which heads the first conjunct 
VP. In Scandinavian, the conjunction is immediately adjacent to a following verb, which heads the second conjunct VP. Yet with regard to this property, Yiddish patterns with Scandinavian - constituent order is somewhat flexible within VP, yet in all the examples, the conjunction is immediately adjacent to a following verb, which heads the second conjunct VP. Why does Yiddish pattern with Scandinavian in this regard?

The third puzzle concerns the syntax of the construction in Icelandic: if Icelandic has V-to-T in all finite clauses, as in (49), then the null-object version of (50) should be ungrammatical, just like (18) in Yiddish - but (50) is good. How and why do the languages differ in this regard?

So, Sten, over to you ...

\section{References}

Åfarli, Tor, \& Chet Creider. 1987. Nonsubject pro-drop in Norwegian. Linguistic Inquiry 18. 339-45.

Christensen, Kirsti Koch. 1986. Norwegian ingen: A case of post-syntactic lexicalization. In Östen Dahl \& Anders Holmberg (eds.), Scandinavian syntax, 21-35. Stockholm: University of Stockholm, Institute of Linguistics.

Dalrymple, Mary, \& Irina Nikolaeva. 2011. Objects and information structure. Cambridge: Cambridge University Press. doi:10.1017/CBO9780511993473

Egerland, Verner. 1996. The syntax of past participles: A generative study of nonfinite constructions in Ancient and Modern Italian. Lund: Lund University Press.

Evans, Gareth. 1980. Pronouns. Linguistic Inquiry 11. 337-362.

Faarlund, Jan Terje, Svein Lie \& Kjell Ivar Vannebo. 1997. Norsk referensegrammatik. Oslo: Universitetsforlaget.

Falk, Hjalmar \& Alf Torp. 1900. Dansk-Norskens syntaks. Kristiania: H. Aschehoug.

Holmberg, Anders. 1986. Word order and syntactic features in the Scandinavian languages and English. Stockholm: University of Stockholm, Department of Linguistics.

Johnsen, Lars G. 1988. A note on subcoordination. University of Trondheim Working Papers in Linguistics 6. 195-201.

Larson, Martha Anne. 2005. The empty object construction and related phenomena. Doctoral dissertation, Cornell University.

Nikolaeva, Irina. 2001. Secondary topic as a relation in information structure. Linguistics 39. 1-49. doi:10.1515/ling.2001.006 
Pouplier, Marianne. 2003. Referential subject and object gaps in Modern Icelandic. In Anne Dahl, Kristine Bentzen \& Peter Svenonius (eds.). Nordlyd 31. 356-371. doi: $10.7557 / 12.8$

Rögnvaldsson, Eiríkur. 1990. Null objects in Icelandic. In Joan Maling \& Annie Zaenen (eds.), Syntax and Semantics 24: Modern Icelandic syntax, 367-379. New York: Academic Press.

Sadock, Jerrold A. 1998. A vestige of verb final syntax in Yiddish. Monatshefte für deutschsprachige Literatur und Kultur 90, University of Wisconsin. 220-226.

Sells, Peter. 2001. Structure, alignment and optimality in Swedish. Stanford: CSLI Publications.

Sigurðsson, Halldor, \& Joan Maling. 2010. The empty left edge condition. In Michael T. Putnam (ed.), Exploring Crash-Proof Grammars, 59-86. Amsterdam/Philadelphia: John Benjamins Publishing Company.

Svenonius, Peter. 2000. Quantifier movement in Icelandic. In Peter Svenonius (ed.), The derivation of $V O$ and $O V$, 255-292. Amsterdam/Philadelphia: John Benjamins. doi:10.1075/la.31.10sve

Teleman, Ulf, Staffan Hellberg \& Erik Andersson. 1999. Svenska Akademiens grammatik. Stockholm: Svenska Akademien.

Thráinsson, Höskuldur. 2007. The syntax of Icelandic. Cambridge: Cambridge University Press.

Vikner, Sten. 1995. Verb movement and expletive subjects in the Germanic languages. New York: Oxford University Press.

Vikner, Sten. 2001. Verb movement variation in Germanic and optimality theory. Habilitationsschrift, University of Tübingen.

Vikner, Sten. 2003. Null objects under coordination in Yiddish and Scandinavian. In Lars-Olof Delsing, Cecilia Falk, Gunlög Josefsson, \& Halldór Á. Sigurðsson (eds.), Grammar in focus: Festschrift for Christer Platzack, 365-375. Lund: Dept. of Scandinavian Languages, University of Lund.

Ximenes, Cristina. 2007. Object gap in Icelandic and short object movement. Manuscript, MIT. Available on lingbuzz: http://ling.auf.net/lingBuzz/000458. 